\title{
Formation of Students Social and Environmental Competence in Inclusive Vocational Education
}

\author{
Chekanovskiy E.N. \\ Samara State Technical University \\ Samara, Russia \\ elenacheka@mail.ru
}

\author{
Kolyvanova L.A. \\ Samara State Pedagogical University \\ Samara, Russia \\ larisaleksandr@yandex.ru
}

\author{
Krygina E.V. \\ Tolyatti Socio-Pedagogical College \\ Samara, Russia \\ kateno4ek8@gmail.com
}

\begin{abstract}
The formation of students social and environmental competence in all areas and profiles of training is most effective in the system of inclusive education, providing the solution of professional problems in the training of future specialists with disabilities and the development of their needs in further interaction with the environment. Therefore, the main task of the teaching staff is to disclose the content of social and environmental education of such students, its basic approaches and principles of implementation, as well as social and environmental design of the vocational school educational environment. It should be noted that to solve this problem it is necessary to create an optimal system-permanent-introvertivebasic environmental training of persons with disabilities, aimed at the effective formation of their social and environmental competence. In the course of our study, special attention was paid to the state of memory, fatigue and social activity of students with disabilities in the process of their training, in order to develop cognitive interest in the implementation of professional activities in the socio-ecological environment. We presented a total indicator of students with disabilities socio-environmental competence formation in vocational education, designed to form their readiness to work in any current socio-environmental situation.
\end{abstract}

Keywords-inclusive professional education; social and environmental competence; students with disabilities; social and environmental training.

\section{INTRODUCTION}

In today's world, dynamically developing technologies that are necessary for a person to effectively live, automatically generate environmental degradation, which negatively affects not only his health, safety and well-being, but also self-development and competitiveness in the labor market.

To date, overcoming the arising environmental problems is possible through the establishment of continuous environmental education aimed at the acquisition of systematized knowledge about the interaction of society with environment, legal, and moral foundations of the nature, methods, means and ways to ensure a constructive approach to the implementation of system "person-environment-societyprofessional activities" sustainable development ideas.

\section{LITERATURE REVIEW}

According to the research conducted by specialists of the Higher school of Economics and the center for strategic studies, within the framework of the project of the Russian education reform, human capital is the most important factor in the socio-economic development of the country, being the same resource as natural resources. At the same time, an important factor in the development of human capital, contributing to the formation of educated, moral and creative professionals in the field of their activities, with certain professional competencies, is a continuous education system aimed at "learning throughout life" [8].

It should be noted that at present, high relevance is the formation of all directions and profiles of training students socio-ecological competence as an integrative totality of environmental competencies, reflecting their ability and readiness on the basis of the acquired environmental knowledge, skills and professionally significant personal qualities (motivation, emotional capacity, etc.) to the analysis, an adequate assessment of specific environmental situation and find a generalized method or procedure successful professional solutions, practical implementation of the environmental problem " [11]

Based on the analysis of scientific literature, in the system of vocational education there are theoretical prerequisites for its study [17]. First of all, it should be noted the research of S. N. Glazachev [6], O. E. Perfilova [16], which outlined the purpose, objectives and content of social and environmental education, analyzed its main approaches and principles of implementation. The scientific works of $\mathrm{Yu}$. M. Grishaeva [7], E. A. are devoted to the socio-ecological design of the educational environment of the University. In 
[9], defined by definitions: "ecological consciousness of personality", "ecological thinking", "ecological model of behavior", "socio-environmental responsibility", "socioecological culture of personality" and "social-ecological competence" in the works of O. S. Anisimov [1], M. Kh., Akhmetova [2], E. Y. Bobkova [3] A. G. Busygin [4], E. V. Lidskii [15], S. I. Nekrasov [12], G. V. Panina [14], V. I. Panov, L. Y. Chuikova [20] and others [18].

\section{RESULTS}

It should be noted that an important aspect in the implementation of professional activities is the understanding of the social and environmental context, adequate awareness of their actions, personal responsibility for the state and preservation of the social environment. In his research M. H. Akhmetov [3], E. Yu. Bobkova [3], T. A. Magsumov [3], Ya. Maximov [3] note that environmental education is aimed at ensuring the transfer of students reliable, scientifically sound information of an environmental nature, thereby facilitating the transfer of their knowledge and ideas about the environment in practice in accordance with the current conditions of life.

In the work of V. V. Falileev [19] it is said that the system of social and environmental education of young people should be built in such a way that under certain moral guidelines to help them successfully adapt to changing environmental conditions, forming appropriate behavioral skills and teaching to foresee the consequences of their social activity and professional activity.

Of particular scientific interest is developed and tested by S. N. Glazachev [6] and O. E. Perfilova [16] program of students social and environmental competence formation, which is based on the modular concept of their training. Revealing the content of the "social and environmental competence" concept, the authors characterize it from the point of view of the students' readiness to be subjective in the perception of the surrounding reality natural and socio-cultural components in the understanding of social responsibility for work [22].

After analyzing the problems of students socioecological competence development, in terms of the social and environmental consciousness certain components formation, it should be noted, research in this field scientists Kursk state University L. A. Molotov [5] and Yu. N. Shirakabako [5] in which the authors outline approaches, principles, pedagogical conditions, criteria and levels of its implementation in science education. A lot of important interest are research works Ulyanovsk Institute of Civil Aviation teachers. Air chief Marshal B. P. Bugaev notes the formation of students socioenvironmental competence using a combined model of studying environmental educational disciplines, such as "life Safety", "life Safety in examples and tasks", "Methods and devices for monitoring environmental parameters" [13].

Thus, based on the results of environmental training systems multi-criteria comparative analysis in Russian universities (system of fragmentary-basic environmental training; system of permanent basic environmental training; system of permanent introverted (from lat. "intro" - inside and "vertere" - to turn, rotate) environmental training; system permanent-introvertive-base) revealed that the optimal system type for maximum achievement of the objectives according to the students ecological competence level, the cognitive scale learning with minimum time costs and amount of labor has a system of permanent-introvertive-basic environmental training [10]. It is especially important for education of persons with disabilities and disability.

Having analyzed scientific works of L. A. Molotov [5] and $\mathrm{Yu}$. N. Simkovicova [5], we outlined the main levels in the structure of students with disabilities socio-ecological competence in the process of their professional training (empirical, methodological, esoteric and behavioral) by which they were able not just to "get involved" in the problems of the environment with the subsequent need for the development of knowledge, but also to develop a clear strategy for rational interaction with the environment. The effectiveness of our study was determined by the data obtained at the ascertaining stage of experimental work and the data of its control stage using the same methods.

The changes that occurred at the empirical level of social and environmental competence formation in students with disabilities were determined by a logical analysis of the of such respondents' sensory cognition (sensation, perception) forms in the surrounding reality.

The study revealed that students of the course I considered the relationship with nature as part of everyday life, while, as for the majority of graduates in the experimental group, this interaction became personalistic demand for casual labour (odds mastering the basic concepts of socio-ecological orientation varied from $0,53-0,78$, with a max $=1$ ).

Using the technique of the author mediated remembering his productivity "Icon" and the nature of mental activity A. R. Luria, we carried out a study on the status of memory, fatigue and activity and attention of students with disabilities in their learning process in GAPO " Tolyatti socio-pedagogical College". It allows to determine their logical memory and emotional state, with the aim of cognitive activity individual features development to social and ecological environment.

As a result, it was revealed that students with disabilities in the I and II courses (68.3\%) had the type of "thinker", which testified to their desire to generalize the information received, its analysis, as well as a high level of abstract and logical thinking, while graduates $(83.8 \%)$ demonstrated concrete-effective (practical) thinking, characterized by direct perception of the objects around them, and aimed at solving specific problems in professional activity.

\section{DISCUSSION}

This result of the study was the reason for determining the esoteric level of social and environmental competence formation in students with disabilities using the method of Charles Osgood semantic differential, aimed at measuring the connotative value of stimulus-stimulus and meaningful work perception with persons with disabilities. In other words, this technique contributed to obtaining adequate information about the rather subtle psychological structures of students ' perception of the world and its differences in the individual 
objects perception. Thus, we proposed a study of healthy students and students with disabilities social and environmental situation perception specifics, which took into account the fact of their interaction with each other. As a result, it was revealed that healthy College students who have a more complete understanding of the environmental situation in the area of their daily stay (territorial and social) assess the environment as prosperous, while students with disabilities who do not have full experience of communicating with healthy people and the environment, treat it less positively (by the factor of "Assessment" autostereotypes are more favorable than heterostereotypes), without expressing any negative emotions. This fact indicates a fairly calm interaction with each other in the process of training.

Determination of the behavioral level of social and environmental competence formation in students with disabilities was carried out by us with the help of volitional self-control determination method, the authors of which are A. G. Zverkova and E. V. Eidman. This technique is aimed at a generalized assessment of the individual level of students' volitional regulation development, which is understood as a measure of mastering their own behavior in different situations - the ability to consciously control their own actions, States and motives.

So, based on the obtained results, it should be noted that students with disabilities I. course have a low rate of volitional self-control ( 2 points - women, 5 scores - men), indicating that their inability to possess himself in certain situations, at the time, as graduates demonstrate ability to consciously control our own actions, state and intentions in any situation (7 women, 11 men).

\section{CONCLUSION}

Summing up the results of the study, it is necessary to conclude that we identified a cumulative indicator of students with disabilities socio-environmental competence formation in inclusive education, the list of which was developed in order to form their readiness to carry out professional activities in any socio-ecological situation. In our opinion, the data obtained in the course of the study indicate a stable increase in the level of socio-environmental competence of students with disabilities in the process of their education $(0.549-0.838)$. It indicates their positive attitude not only to natural and social phenomena, but also to professional activity, determined by the level of their intellectual, moral, cultural development, as well as social position and Outlook.

Thus, our analysis of the problem of students in inclusive vocational education social and environmental competence formation makes a significant contribution to the solution of socially important tasks of modern society - the development of persons with disabilities professional abilities formation system in the resolution of certain everyday social and environmental situations, thereby contributing to their successful socialization in the environment.

\section{References}

[1]. Anisimov, O. S. Socio-ecological competence: the program and guidelines for the course (review). Bulletin of economic education in Russia. 2007, 2, pp. 16-17.
[2]. Akhmetov M.H. Social aspects of industrial cities students' ecological competence formation (on materials of the Republic of Tatarstan). VEPS. 2012, 1, pp. 275-277. URL: https://cyberleninka.ru/article/n/sotsialnye-aspekty-formirovaniyaekologicheskoy-kompetentnosti-uchascheysya-molodyozhipromyshlennyh-gorodov-na-materialah.

[3]. Akhmetov, M. H., Bobkova E.Y., Magsumov T.A., Maximov J.A. Environmental practices as a way of students environmental behaviours internalization. the SISP. 2017, 7, pp. 330-346 URL: https://cyberleninka.ru/article/n/ekologicheskie-praktiki-kak-sposobinteriorizatsii-ekologicheskoy-modeli-povedeniya-uchascheysyamolodyozhi

[4]. Busygin, A. G. Desmolase or the theory of education for sustainable development. Book one. 2nd ed. Ulyanovsk: Publishing house "Siberian book". 2003, 216.

[5]. Gvozdeva, L. A., Sorokovikova, Yu. N. The formation of socioecological competence in science education. Scientific notes: electronic scientific journal of the Kursk state University. 2013, 3 (27), vol. 2, pp. 181-186.

[6]. Glazachev, S. N. Socio-ecological competence as an element of basic human competence. Bulletin of environmental education in Russia. 2007, 3, pp. 23-24.

[7]. Grishaeva, Yu.M. Ecological and educational environment of the University. Astrakhan Herald of ecological education. 2012, 1, pp. 8790 URL: https://cyberleninka.ru/article/n/ekologo-obrazovatelnoeprostranstvo-vuza

[8]. Kolyvanov, L.A., Ermakova J.D., Nosova T.M., Bolshakov Yu.S. Science, environmental literacy in professional education. Journal "Vocational Secondary Education". 2019, 6, pp. 56-62.

[9]. Ksenofontov, E. A. Socio-environmental design in the educational environment of the University. Astrakhan Bulletin of environmental education. 2014, 2(28), pp. 102-104 URL: https://cyberleninka.ru/article/n/sotsialno-ekologicheskoeproektirovanie-v-obrazovatelnoy-srede-vuza

[10]. Mihaljevic, V.N., Chekanovskiy E.N. Comparative analysis of technical universities students ecological competence system formation. Oil and gas sector: issues and innovations. The abstracts of the III scientific.-practical. Conf. with int. participants. Samara: Samar. GOS. tehn. Univ. 2018, pp. 174.

[11]. Mihaljevic, V.N., Chekanovskiy E.N. The system of continuous introvertive-basic environmental training of engineering and technology bachelors. Scientific journal "Academic review will SPIT". Tolyatti: Publishing house "ELPIT". 2017, 1 (2), vol. 2, pp. 33-44.

[12]. Nekrasov S.I., Serezhkin, A.A. Essence and structure of social and environmental responsibility. Scientific Bulletin of MSTUCA. 2012, 182, pp. 89-93. URL: https://cyberleninka.ru/article/n/suschnost-istruktura-sotsialno-ekologicheskoy-otvetstvennosti

[13]. Nechaeva, O. A. the use of combined training in the formation of socioenvironmental competence in aviation University. Historical and socioeducational thought. 2017, 9(6/2), pp. 243-248. DOI: https://doi.org/10.17748/2075-9908-2017-9-6/2-243-248.

[14]. Panina, G. V. Socio-humanitarian disciplines in universities as a means of personality ecological culture formation. Bulletin of the MSFU energy physics. 2011, 2, pp. 180-184. URL: https://cyberleninka.ru/article/n/sotsialno-gumanitarnye-distsipliny-vvuze-kak-sredstvo-formirovaniya-ekologicheskoy-kultury-lichnosti

[15]. Panov, V.I., Leeds E.V. the Concept of sustainable development: ecological thinking, consciousness, responsibility. Socialenvironmental technology. 2012, 1, pp. 38-50. URL: https://cyberleninka.ru/article/n/kontseptsiya-ustoychivogo-razvitiyaekologicheskoe-myshlenie-soznanie-otvetstvennost

[16]. Perfilova, O. E. the Development of socio-environmental competence of the teacher in professional education: abstract dissert. for the degree of candidate of pedagogical Sciences. M.: RIO MGTU named after M.A. Sholokhova. $2007, \quad 29$ URL: https://cyberleninka.ru/article/n/sotsialno-ekologicheskayakompetentnost-kak-pedagogicheskaya-kategoriya

[17]. Reznichenko, V. A. Modern paradigm of the all-Russian scientificpractical conference engineering activities Proceedings (November 1920, 2008)"Problems and prospects of teaching social and humanitarian Sciences in technical universities in modern conditions". - Moscow. 2008, pp. 192-195. 
[18]. Semenov, A. A., Saito, H. Formation and development of school biological education in modern Russia. Samara scientific Bulletin. 2018, vol. 7, 3(24), pp. 339-343.

[19]. Falileev, V. V. Socio-ecological culture of personality as a factor of tolerance. Vestnik KemGU. 2008, 4, pp. 100-105.

[20]. Chuikova, L. Y. The Problem of the personality ecological culture and environmental consciousness stability in modern conditions. CiO. 2012, 1, pp. 49-53. URL: https://cyberleninka.ru/article/n/problemaustoychivosti-ekologicheskoy-kultury-i-ekologicheskogo-soznaniyalichnosti-v-sovremennyh-usloviyah

[21]. Alexsandr S. Kuznetsov. Russian Professor's meeting. Russian Journal of Physical Education and Sport. 2019, 14(1), pp. 17-22. DOI: $10.14526 / 2070-4798-2019-14-1-18-24$ 